Jurnal Riset Biologi dan Aplikasinya

\title{
Variation and Phenetic Relationship of Tobacco (Nicotiana tabacum L.) In Central Java and Yogyakarta Based on Morphological Characters
}

\author{
Agung Dwi Santoso ${ }^{1 *}$, Purnomo \\ ${ }^{1}$ Faculty of Biology, Universitas Gadjah Mada \\ ${ }^{2}$ Plant Systematics Laboratory, Faculty of Biology, Universitas Gadjah Mada \\ Jln. Teknika Selatan, Senolowo, Sinduadi, Mlati, Sleman, Yogyakarta 55281 \\ *Corresponding Author: \\ e-mail: agung.dwi.santoso@mail.ugm.ac.id
}

\section{Article History \\ Received : 10 June 2021 \\ Revised : 21 July 2021 \\ Approved : 29 August 2021 \\ Published : 30 September 2021}

\section{Keywords}

tobacco; macromorphology; micromorphology; phenetic relationship

\begin{abstract}
Tobacco (Nicotiana tabacum L.) is a plant used as a mixture of cigarettes, and recreational media especially for men. This study aimed to identify variations, and determine the relationship between tobacco cultivars in Central Java and Yogyakarta based on macromorphological and micromorphological characters. Sampling locations are determined by surveying locations in both regions. Tobacco samples found include 5 cultivars in Central Java namely 'Mantili', 'Uler Magetan', 'Garut', 'Gober Boyolali', 'Manila', and 3 cultivars in Yogyakarta namely 'Siluk', 'Java', and 'Virginia'. Characterization with 23 qualitative macromorphological characters including leaves, and stems, with 9 qualitative and quantitative micromorphological characters including trichome and stomata. Descriptive data analysis is done to obtain the typical character of each cultivar, followed by numerical analysis including scoring characters processed with MVSP (Multi Variate Statistical Package), clustering with UPGMA (Unweighted Pair Group Method with Averages), and calculation of similarity coefficients with Simple matching formula. The results showed variations in the macromorphological characters including the shape of the leaf lamina, the base of the leaf, the absence of leaf stalks, and type of leaf venation. Tobacco has anisositic stomata, and varies in terms of length, width, and density of stomata. Tobacco trichomes are glandular. The result dendrograms form two clusters (A and B) with the similarity index of each cluster above 0.80. Cultivars with close relationships such as 'Siluk'-'Java', and far relationship like 'Java'-'Manila'.
\end{abstract}

How to cite: Santosa, A.D., \& Purnomo. (2021). Variation and Phenetic Relationship of Tobacco (Nicotiana tabacum L.) in Central Java and Yogyakarta Based on Morphological Characters. Jurnal Riset Biologi dan Aplikasinya, 3(2): 73-79. DOI: $10.26740 /$ jrba.v3n2.p73-79.

\section{INTRODUCTION}

Tobaccos are commercial plant from the family Solanaceae, used widely as offerings in traditional ceremonies, herbal medicine ingredients, and main ingredient of cigarettes for personal entertainment. In Indonesia tobaccos could grow around 15 provinces ranging from lowland such as Nusa Tenggara to highland such as Wonosobo (Djajadi, 2015). Various cultivars appear in Indonesia, making tobacco plants widespread and adaptable. Many tobacco cultivars appear because of cultivation by crossing various inductees in order to obtain superior offspring with good nicotine levels suitable for cigarette mixtures (Amelia, 2012). Cultivars are individuals with similar character within species, and are distinguishable from other cultivars (Federizzi et al., 2012). The development of cultivars makes identification and characterization become the first step to introduce and developing of tobacco's cultivation in the community (Korir et al., 2012). Research of tobacco cultivars such as Djumali (2011) about identification 
and characterization of tobacco cultivars found in Temanggung. This research has found various tobacco cultivars such as 'Kemloko-1','2', and ' 3 ', 'Dorowati,' 'Mantili', etc. According to this study variations present from leaf morphology such as different sizes and shapes, leaf color, harvest age, and flowers morphology typical in each type of cultivars.

The variety character of tobacco cultivars is quite diverse and specific in certain habitats. This is the result of environmental adaptation and the cultivation process carried out by farmers (Amelia, 2012; Prasetiyo et al., 2016). These adaptive variations are reflected through the morphological and anatomical characters of the plant. Variations in morphological characters are still commonly used for the identification process, and grouping different types of cultivars through phenetic approach. The phenetic analysis is an activity that grouping organisms into specific groups based on visible character equations, which exist in organisms regardless of their evolution (Arrijani, 2003). This grouping is expected to make it easier for researchers and cultivators to know the genealogy and cultivars' relationship. Variations in organisms become the guideline for choosing inductees with the best quality to produce better offspring. Thus, this study was conducted to determine the variation, and relationship of tobacco cultivars in Central Java and Yogyakarta using morphological characters through phenetic analysis.

\section{MATERIALS AND METHODS}

Table 1. Tobacco cultivars studied in this research

\begin{tabular}{lll}
\hline No & Cultivar's Name & Location \\
\hline 1 & 'Mantili' & Parakan, Temanggung, Jawa tengah \\
2 & 'Uler Magetan' & Parakan, Temanggung, Jawa tengah \\
3 & 'Garut' & Parakan, Temanggung, Jawa tengah \\
4 & 'Gober Boyolali' & Parakan, Temanggung, Jawa tengah \\
5 & 'Manila' & Parakan, Temanggung, Jawa tengah \\
6 & 'Virginia' & Pleret, Bantul, Yogyakarta \\
7 & 'Jawa' & Pleret, Bantul, Yogyakarta \\
8 & 'Siluk' & Imogiri, Bantul, Yogyakarta \\
\hline
\end{tabular}
Figure 1. micromorphological characters. Matching coefficient formula.

$$
\frac{(a+d)}{(a+b+c+d)}
$$
Aggarwal, 2019) UPGMA algorithm. 2021 in Temanggung and Yogyakarta. The samples used were leaves, stems, and flowers from eight tobacco cultivars listed in Table 1 and pictured in

The observations are using 23 macromorphological characters and 7 micromorphological characters of qualitative and quantitative chosen from previous study about tobacco. Characterization of macromorphological characters using leaves (adaxial side), flowers, fruits, and stems. Leaves samples are also taken to be preserved. The leaves are then coated by nail polish to print the leaves surface. The print observed with microscope to characterize the

The descriptive analysis was done using the existing characters; to obtain the identification key. Then cluster analysis used to generate two dendrogram for each observed macromorphological and micromorphological characters. Dendrogram construction starts from character scoring and coding, calculation of similarity index with Simple

Description : $a=$ number of second properties of data 1 , $b=$ number of properties of the first data 1 second data 0 , $\mathrm{c}=$ number of properties of the first data 0 second data 1 , $\mathrm{d}=$ number of properties of the second data o (Verma and

Analysis are continued by constructing similarity matrix using MVSP 3.2A, and clustering with 
Table 2. Scoring and Coding of Macromorphologicals Characters of Tobacco Cultivars

\begin{tabular}{|c|c|c|}
\hline No & Characters & Score \\
\hline 1 & Habit & Herbs $=0$, Shrubs $=1$ \\
\hline 2 & Leaf Position in Stem & Alternate $=0$, Distichous $=1$ \\
\hline 3 & Leaf Stipule & Absent $=0$, Stipula $=1$ \\
\hline 4 & Presence of Petiole & No $=0$, Yes $=1$ \\
\hline 5 & Leaves Apex & Acute $=0$, Attenuate $=1$ \\
\hline 6 & Leaves Base & Truncate $=0$, Rounded $=1$ \\
\hline 7 & Leaves Margin & Entire $=0$, Waved $=1$ \\
\hline 8 & Trichomes on Leaves Adaxial Surface & Low $=0$, Moderate $=1$ \\
\hline 9 & Lamina Shape & Ovate $=0$, Lanceolate $=1$ \\
\hline 10 & Leaves Colour & Lighter shade $=0$, Darker shade $=1$ \\
\hline 11 & Petiole & Decurrent $=0$, Petiolate $=1$ \\
\hline 12 & Stomata Position & Epistomatic $=0$, Amphistomatic $=1$ \\
\hline 13 & Leaves Venation & Camptodromus $=0$, Penninerved $=1$ \\
\hline 14 & Stem based of Shoots Growth & Monopodial $=0$, Simpodial $=1$ \\
\hline 15 & Stem based of Growth Direction & Erect $=0$, Ascendens $=1$ \\
\hline 16 & Flower Arrangement & Raceme $=0$, Panicle $=1$ \\
\hline 17 & Flower Type & Simple $=0$, Compound $=1$ \\
\hline 18 & Flower Position & Axillar $=0$, Terminal $=1$ \\
\hline 19 & Petal Colour & White $=0$, Pink $=1$ \\
\hline 20 & Sepal Colour & Light Green $=0$, Green $=1$ \\
\hline 21 & Corolla Symmetry & Actinomorphic $=0$, Zygomorphic $=1$ \\
\hline 22 & Fruit Shape & Round $=0$, Elliptical $=1$ \\
\hline 23 & Fruit Color & Green $=0$, Brown $=1$ \\
\hline
\end{tabular}

Table 3. Scoring and Coding Micromorphologicals Characters of Tobacco Cultivars

\begin{tabular}{lll}
\hline No & Characters & Score \\
\hline 1 & Stomatal Type & Anisositic $=0$, Parasitic $=1$ \\
2 & Stomatal Length & $<40 \mu \mathrm{m}=0,>40 \mu \mathrm{m}=1$ \\
3 & Stomatal Width & $<20 \mu \mathrm{m}=0,>20 \mu \mathrm{m}=1$ \\
& & $<40$ individual $/ \mathrm{mm}^{2}=0,>40$ \\
4 & Stomatal Density & individual $/ \mathrm{mm}^{2}=1$ \\
5 & Trichome's Gland Shape & Round $=0$, Ellips $=1$ \\
6 & Glandular Trichome & Yes $=0$, No $=1$ \\
7 & Trichome Length & $<400 \mu \mathrm{m}=0,>400 \mu \mathrm{m}=1$ \\
\hline
\end{tabular}

\section{RESULT AND DISCUSSION Morphological Character Variations}

The characterization results indicate variations in some characters. Macromorphological characters include the shape of the leaf lamina, the base of the leaves, the presence of petiole, and the type of leaf venation. Tobacco has anisocytic stomata and glandular type trichomes. Morphological characters are commonly used in determining the taxon of organisms either genus, species, or more specifically (Awan and Murtaza, 2016). The distinctive macromorphological character of tobacco cultivars, is the presence of petiole in some types of cultivars. Some cultivars have seated leaves, so the base of the leaves have wider size. This part has a distinctive wavy shape like a wing (Figure 2). In contrast to tobacco cultivars with petiolated leaves, where leaf wings are absent. The petiolated leaves will be more rounded because the base of the leaves' form a certain angle before meeting on the stalk. Then the leaves width at the bottom is wider, so it is shaped like an egg. While seated leaves whose the lamina 
are elongated because the base the leaves' base does not form a certain angle before meeting on the petiole.

Micromorphological character variations are quantitative such as stomata density. Quantitative character measurements are taken in a certain range as the score. Qualitative characters include stomata type, and the trichomes on the sample are likely uniform. Stomata belong to anisocytic type where the stoma is surrounded by several neighbouring cells, that can be distinguished by the surrounding epidermis cells (Dewi et al., 2015) (Figure 3). This type of stomata is also commonly found in other Solanaceae (Awan and Murtaza, 2016; Fajri, 2013). The sample also has a uniform type of trichomes which is glandular (Figure 4).
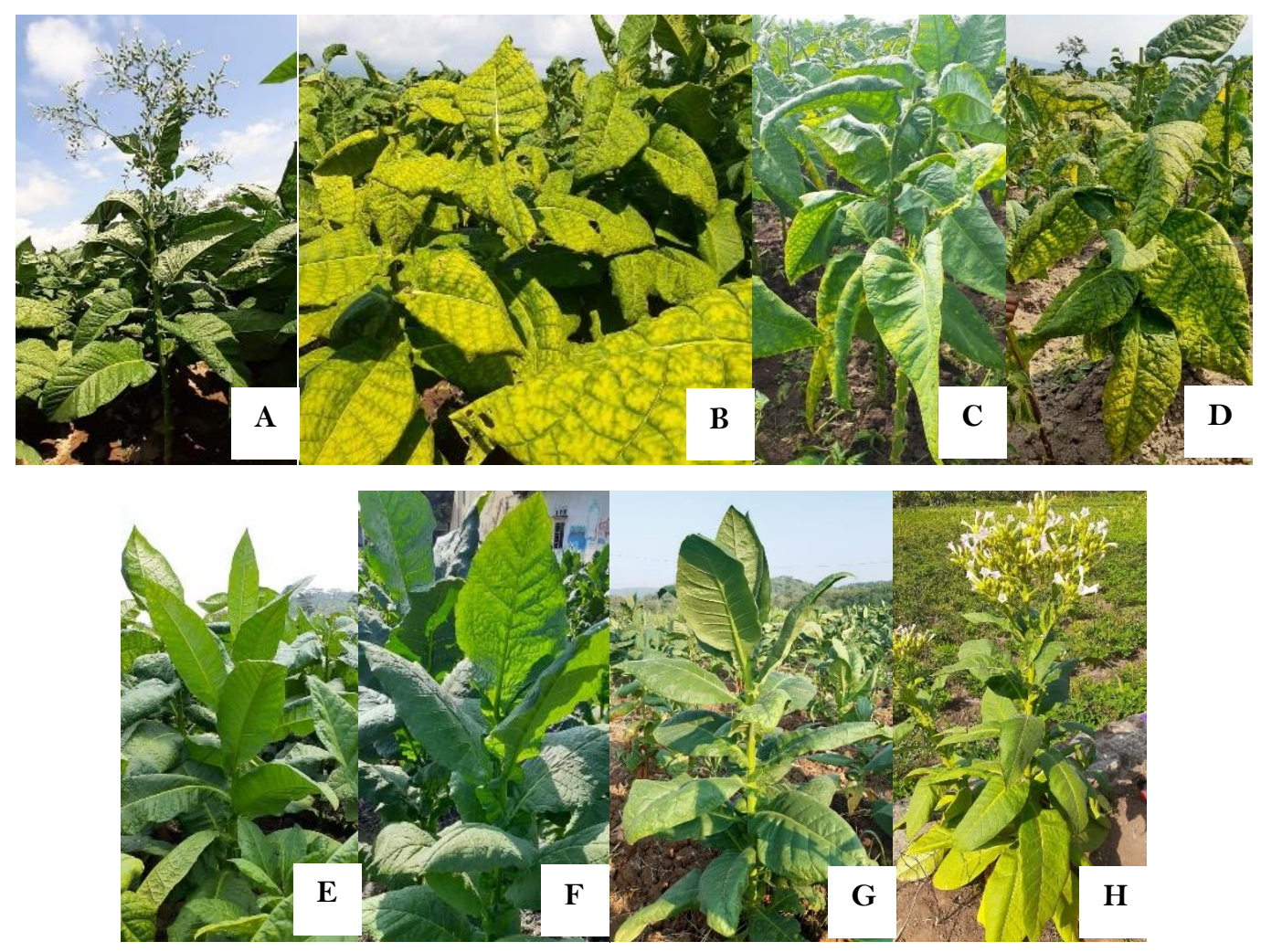

Figure 1. A) Tobacco 'Mantili’, B) Tobacco 'Uler Magetan', C) Tobacco 'Garut', D) Tobacco 'Gober Boyolali', E) Tobacco 'Manila’, F) Tobacco 'Virginia', G) Tobacco ‘Jawa’, H) Tobacco ‘Siluk’

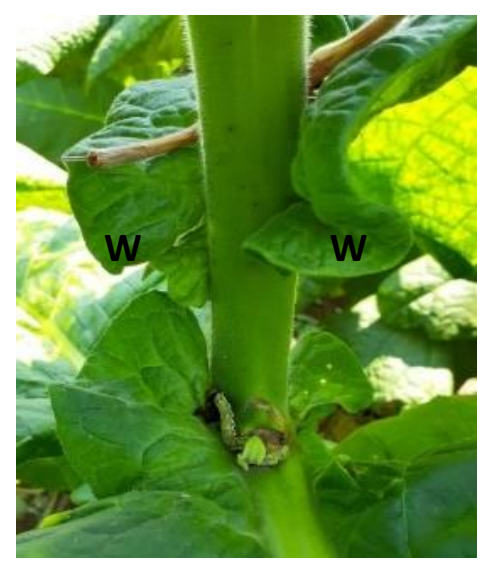

Figure 2. Leaves Wing on Tobacco. W=wing. 


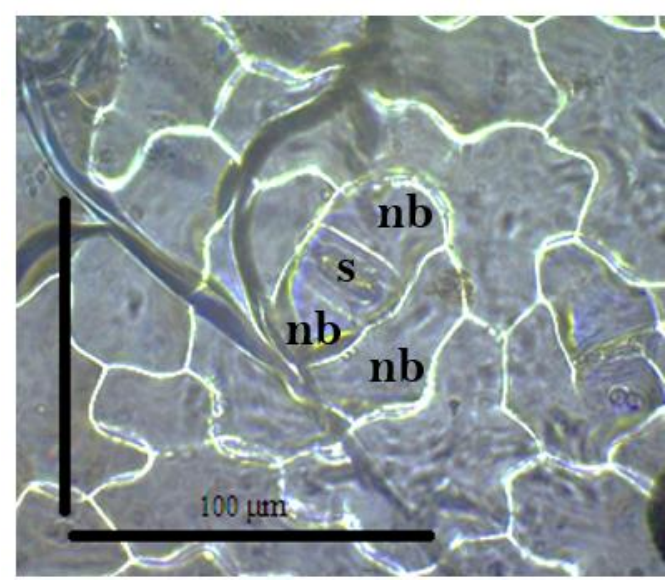

Figure 3. Anisocytic Stomata. s : stoma, nb : neighboring cell.

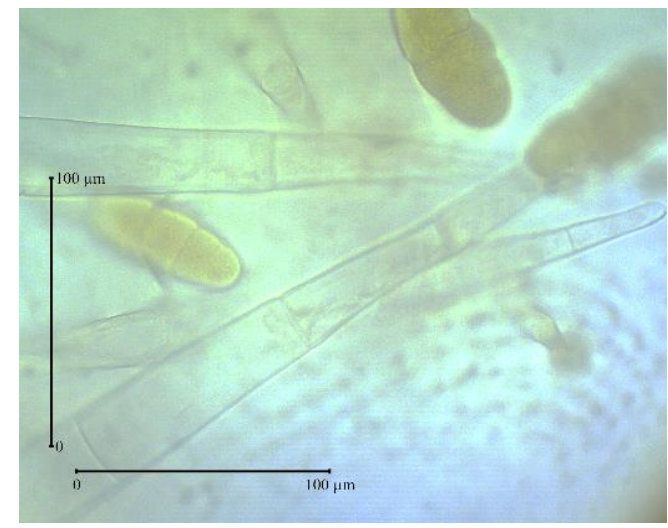

Figure 4. Glandular Trichomes

Table 4. Identification Key for Tobacco Cultivars in Central Java and Yogyakarta

\begin{tabular}{|c|c|}
\hline Macromorphology & Micromorphology \\
\hline 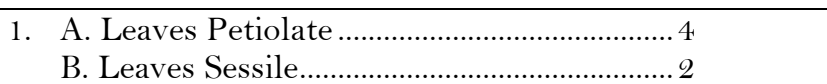 & $\begin{array}{l}\text { 1. A. Stomatal Length }<40 \mu \mathrm{m} \ldots \ldots . . . \text { 'Mantili','Garut' } \\
\text { B. Stomatal Length }>40 \mu \mathrm{m} \ldots \ldots . .2\end{array}$ \\
\hline 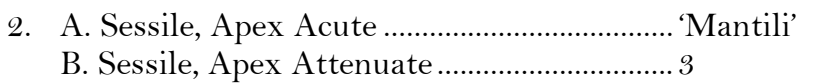 & $\begin{array}{l}\text { 2. A. Stomatal Width }<20 \mu \mathrm{m} \text {........... 'Jawa','Siluk' } \\
\text { B. Stomatal Width }>20 \mu \mathrm{m} . . . \ldots \ldots . .3\end{array}$ \\
\hline $\begin{array}{l}\text { 3. A. Attenuate, Lighter Shade ............................ 'Garut' } \\
\text { B. Attenuate, Darker Shade .......................... 'Gober } \\
\text { Boyolali' }\end{array}$ & $\begin{array}{l}\text { 3. A. Stomatal Density }<40 \mu \mathrm{m}^{2} \text {....... 'Manila', 'Gober } \\
\text { Boyolali' } \\
\text { B. Stomatal Density }<40 \mu \mathrm{m}^{2} \text {...... 'Virginia', 'Uler }\end{array}$ \\
\hline 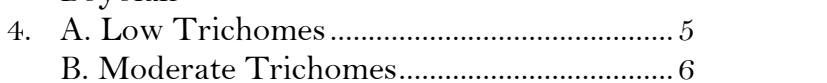 & 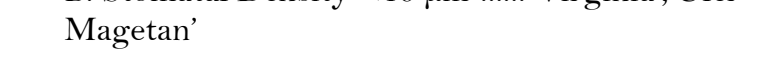 \\
\hline $\begin{array}{l}\text { 5. A. Low Trichomes, Lighter Shade.................. 'Virginia' } \\
\text { B. Moderate Trichomes, Darker Shade ........ 'Manila' }\end{array}$ & \\
\hline $\begin{array}{l}\text { 6. A. Lamina Ovate ...............................................'Uler } \\
\text { Magetan' }\end{array}$ & \\
\hline $\begin{array}{l}\text { B. Lamina Oblong .......................................... ' } 7 \\
\text { 7. A. Oblong, Lighter Shade ................................. 'Siluk' } \\
\text { B. oblong, Darker Shade................................... Jawa' }\end{array}$ & \\
\hline
\end{tabular}

Glandular trichomes on leaves could produce certain secretaries for defence and metabolic aid processes (Maryani et al., 2009). In contrast with non-glandular trichomes that are common to plant for defence agents (Fajri, 2013). This variations makes the trichomes one of the characters used commonly in plant systematics. The variations of these characters are then arranged as identification key, to find out the distinctive character of each cultivars. A dendrogram then supports the identification key to determine its relationship (Table 4). 
Based on dendrograms cultivars samples have a similarity index ranging from 0.50 to 1.00 (Figure $5)$. Some cultivars have a similarity index close to $100 \%$ although planted in two different regions. 'Manila' from Central Java is closely related to 'Virginia' and 'Java' from Yogyakarta. The close relationship between cultivars grown in two different regions is caused by similar environmental conditions around the plants. The dendrograms show the existence of two clusters A and B based on the presence of petiole, and the density range of stomata. Cluster A is a cultivar with petiolated leaves, and cluster $\mathrm{B}$ is the sessile leaves.

The cluster A has stomatal density $>40$ ind $/ \mathrm{mm}^{2}$, and cluster $\mathrm{B}$ has stomatal density $<40$ ind $/ \mathrm{mm}^{2}$. In micromorphologys' dendrogam the similarities bertween cultivars are $100 \%$. This means that cultivars in each subclaster have high similar characters, thus its relationship are very close. Both dendrograms show that the sample will have a closer relationship in one cluster, especially for cultivars that grow in one region such as 'Java''Siluk'. A lower similarity index means closer relationships with the sample such as 'Java'-'Manila'. The morphological characters used can also be used to group and know their relationship. The data can be used as a reference to choose iductess with high variation, that when crossed, could produce offspring with better quality for cultivation.

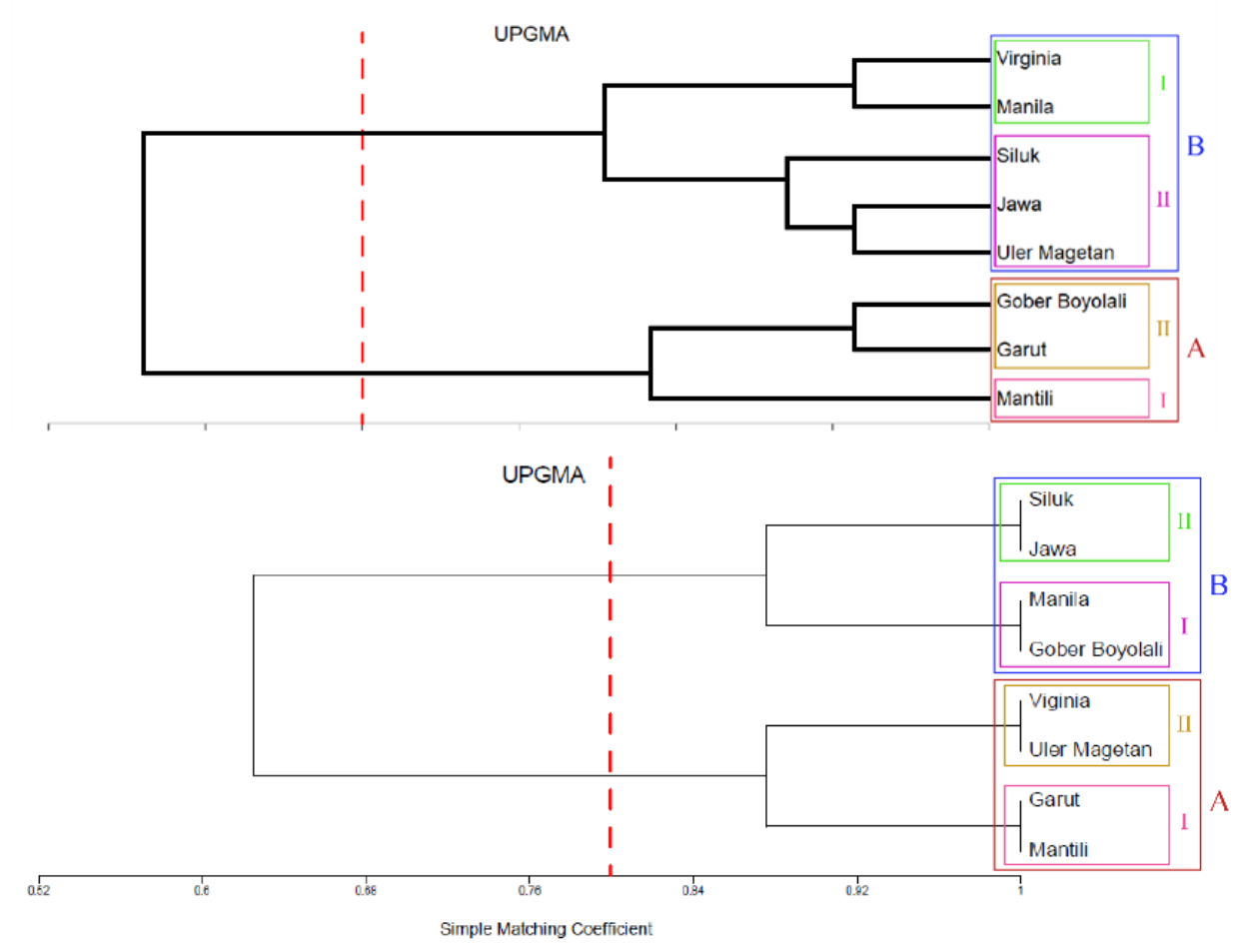

Figure 5. Phenetic relationship dendrogram of tobacco cultivars in Central Java and Yogyakarta based on morphological characters. $a=$ macromorphology, $b=$ micromorphology

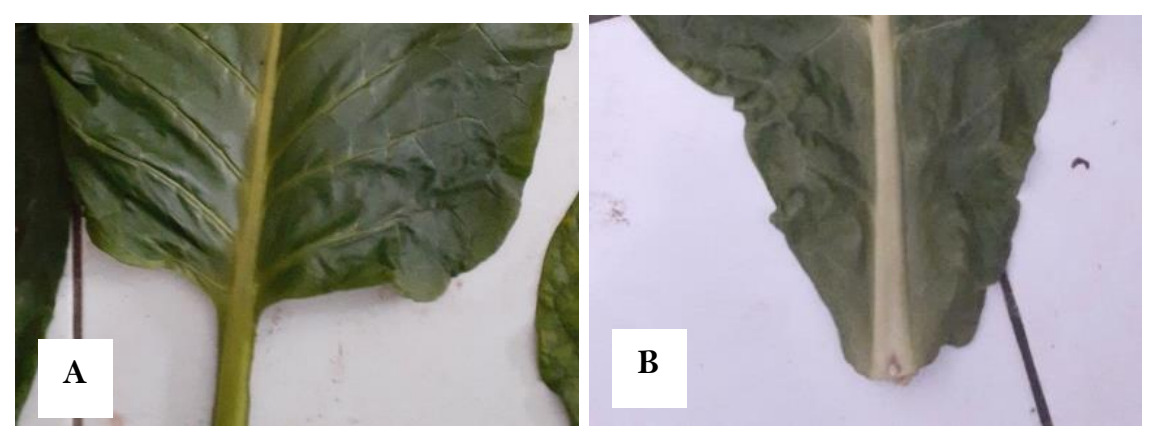

Figure 6. A) Petiolate leaves, B) Sessile leaves 


\section{CONCLUSION}

Tobacco cultivars that can be found include 5 cultivars in Central Java namely 'Mantili', 'Uler Magetan', 'Garut', 'Scrooge Boyolali', 'Manila', and 3 cultivars in Yogyakarta namely 'Siluk', 'Java', and 'Virginia'. Variations of morphological characters are used to construct dendrogram. Dendrograms form two clusters (A and B) with the similarity index of each cluster above 0.80. Cultivars with close relationships are 'Siluk'-'Java', and far related are 'Java'-'Manila'.

\section{ACKNOWLEDGEMENTS}

We would like to thank for colaborative Research of Lecturer and Students of Faculty of Biology, Universitas Gadjah Mada, Indonesia with contract number 1014/UN1/FBI/KSA/PT.01.03/2021.

\section{REFERENCES}

Amelia, A.L. (2012). Hasil Kajian Beberapa Jenis Tembakau Di Indonesia. AgroSaint UKI Toraja. 3 (1), 243-251.

Arrijani. (2003). Kekerabatan Fenetik Anggota Marga Knema, Horsfieldia, dan Myristica di Jawa berdasarkan Bukti Morfologi Serbuk Sari. Biodiversitas. 4 (2), 83-88. Awan, A.A., \& Murtaza, G. (2016). Anatomical Studies on Stomata of Solanaceae from Muzaffarabad Division Azad Jammu Andkashmir, Pakistan. Science International (Lahore). 28 (5), 4701-4706.

Dewi, N.P.S.R., Kriswiyanti, E., \& Sutara, P.K. (2015). Hubungan Kekerabatan 12 Kultivar Brokoli (Brassica oleracea L.) Berdasarkan Karakter Anatomi Stomata. Simbiosis. 3 (1), 291-300.

Djajadi, D. (2015). Tobacco Diversity in Indonesia. Journal of Biological Researches. 20 (1), 27-32.

Djumali. (2011). Karakter Agronomi yang Berpengaruh Terhadap Hasil dan Mutu Rajangan Kering Tembakau Temanggung. Buletin Tanaman Tembakau, Serat Eं Minyak Industri. 3 (1), 17-29.

Fajri, L. (2013). Tipe Trikoma dan Stomata Pada Beberapa Species Hyptis (Labiatae). Eksakta 1, 14, 64-69.

Federizzi, L.C., Carbonell, S.A.M., Pacheco, M.T., \& Nava, I.C. (2012). Breeders' Work After Cultivar Development - The Stage of Recommendation. Crop Breeding and Applied Biotechnology. 2(2), 67-74.

Korir, N.K., Han, J., Shangguan, L., Wang, C., Kayesh, E., Zhang, Y., \& Fang, J. (2012). Plant Variety and Cultivar Identification: Advances and Prospects. Critical Reviews in Biotechnology. 33(2): 111-115.

Maryani, Prabawani, R.L., \& Daryono, B.S. (2009). Struktur Anatomi Epidermis Daun Lima (Cucumis melo L.) Kultivar Melon Berdasarkan Resistensinya terhadap Jamur Tepung (Sphaerotheca fuliginea Poll). Biota.14 (2), 105-114.

Prasetiyo, A., Djajadi, \& Sudarto. (2016). Kajian Produktivitas dan Mutu Tembakau Temanggung Berdasarkan Nilai Indeks Erodibilitas dan Kepadatan Tanah. Jurnal Tanah dan Sumberdaya Lahan. 3 (2), 389399.

Verma, V., \& Aggarwal, R.K. (2019). A New Similarity Measure Based on Simple Matching Coefficient for Improving the Accuracy of Collaborative Recommendations. I.J. Information Technology and Computer Science. 11 (6), 37-49. 